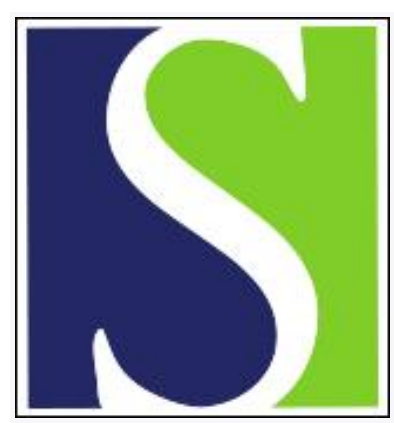

Scand J Work Environ Health 1986;12(4):296-300

https://doi.org/10.5271/sjweh.2149

Issue date: Aug 1986

Vibration-induced white finger among selected underground rock drillers in British Columbia.

by Brubaker RL, Mackenzie CJ, Hutton SG

This article in PubMed: www.ncbi.nlm.nih.gov/pubmed/3490687

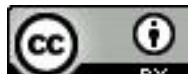




\title{
Vibration-induced white finger among selected underground rock drillers in British Columbia
}

\author{
by Robert L Brubaker, PhD, CJG Mackenzie, MD, FRCP(C), Stanley G Hutton, PhD, ME1
}

\begin{abstract}
BRUBAKER RL, MACKENZIE CJG, HUTTON SG. Vibration-induced white finger among selected underground rock drillers in British Columbia. Scand J Work Environ Health 12 (1986) 296-300. Ninetyfive rock drillers who used pneumatic hand-held drills were interviewed and tested. Thirty-seven were excluded because of factors predisposing to the appearance of white fingers other than exposure to industrial hand-drill vibration. Forty-five percent of the remaining 58 drillers suffered from periodic attacks of Raynaud's phenomenon. Symptoms were present in $25 \%$ of the drillers exposed for $1-5$ years and in $80 \%$ of those exposed for $\geq 16$ years. Nine percent of the cases were classified as severe. The median latency for the onset of the blanching symptoms was 7.5 years. The prevalence of Raynaud's phenomenon was $4 \%$ among a reference group of 56 miners not exposed to hand vibration and corrected for possible predisposing factors. Objective evidence indicated delayed finger rewarming after a combination of digital ischemia and cooling in $75 \%$ of the drillers with blanching symptoms and $18 \%$ of the referents without symptoms. There was evidence of an increased frequency of vibration-induced white finger among current cigarette smokers. Weighted 4-h equivalent acceleration levels measured from the handles of 26 jack-leg and 13 stoper drills from the same mines as the miners ranged from 15 to $32 \mathrm{~m} / \mathrm{s}^{2}$. These levels exceed recommended guidelines of the International Organization for Standardization.
\end{abstract}

Key terms: jack-leg drill, miners, Raynaud's phenomenon, stoper drill, vibration measurements.

Miners exposed to hand-arm vibration from pneumatic rock drills such as jack-leg and stoper drills are at increased risk to develop vibration-induced white finger (VWF). Although many epidemiologic studies conducted worldwide have confirmed this fact, only two have been reported dealing with Canadian miners (1, 19). In addition little information is available on the vibration characteristics of rock drills causing VWF $(4,6,13,15,16,19)$. The purpose of the present study was to investigate the prevalence of VWF among operators of hand-held rock drills in British Columbia and to determine simultaneously the vibration levels of typical drills used in a production capacity.

\section{Subjects and methods}

The study group consisted of all drill operators exposed to hand-arm vibration from pneumatic jack-leg or stoper drills for a minimum of one year and working in the two largest underground hard rock mines in British Columbia. These sites included the Westmin Resources Western Mine on Vancouver Island and the Cominco Limited Sullivan Mine in Kimberly. Work conditions, practices, and equipment for pneumatic drillers are similar for most hard rock mines in British Columbia (BC) and most of Canada. Workers in

\footnotetext{
1 University of British Columbia, 2075 Wesbrook Mall, Vancouver, British Columbia, Canada, V6T 1W5.

Reprint requests to: Dr RL Brubaker, Department of Health Care \& Epidemiology, University of British Columbia, James Mather Building, 5804 Fairview Avenue, Vancouver, BC Canada, V6T 1 W5.
}

British Columbia are typically exposed to $1.5 \mathrm{~h}$ of vibration per shift and are paid a bonus based on footage drilled.

The reference group consisted of volunteer employees at the same mine sites without a prolonged history of intensive hand-arm vibration exposure.

All the subjects were professionally administered a detailed medical and occupational history questionnaire. An objective digital vascular test based on coldinduced inhibition of reactive hyperemia was used in an attempt to verify vascular abnormality (9).

Vascular and neurological symptoms of VWF from the questionnaires were classified according to stages as described by Taylor \& Pelmear (2).

Stage assessment was based solely on subject symptomatology and not on the objective test.

Vibration levels from the handles of the jack-leg and stoper drills (or in a few cases from the air hose of a stoper drill) were measured under actual drilling conditions at the mine sites according to guidelines specified in ISO/DIS 5349.2 (7). Details of the vibration measurement techniques will be published separately.

\section{Results and conclusions}

Ninety-six out of the 106 jack-leg and stoper operators from the two sites participated in the study. Ten were not available to participate due to illness, injury, vacation, or drill exposure of less than one year.

Raynaud's phenomenon can result from medical conditions or vibration exposure other than pneumatic drills. To correct for this situation, we established subgroups, excluding subjects with possible confounding 
factors, as defined in table 1. Drill operators with a history of vibration exposure other than jack-leg or stoper drills and referents with any type of vibration exposure as defined by Lidström (10) were excluded from the subgroups. In addition exclusions were also made for medical conditions such as primary Raynaud's disease, severe hand-arm trauma, and other diseases known to cause a predisposition to Raynaud's phenomenon. As indicated in table 1, $39 \%$ of the driller group and $41 \%$ of the referents were excluded from the subgroups because of possible confounding factors. Data are presented in most cases only for subgroup subjects in order to define more accurately workers with symptoms of VWF resulting from vibration exposure to pneumatic hand-held drills.

Figure 1 indicates the percentage of drillers and referents from each mine site. The total group consisted of 96 drillers and 95 referents, while the subgroup category included 58 drillers and 56 referents.

No significant differences were noted in mean age among the subgroup of drillers [34.7 (SE 0.8) years] and referents [36.7 (SE 1.4) years] in a two-tailed test of proportions.

The prevalence of VWF according to stage of disease is indicated in figure 2. Forty-five percent of the driller subgroup reported blanching symptoms. This difference was statistically significant at $\mathrm{p}<0.001$ (two-tailed test of proportions). Nine percent of the drillers and none of the referents reported advanced stage 3 symptoms. The latency period for the development of Raynaud's phenomenon, as recalled by the operators, ranged from $1-14$ years with a calculated

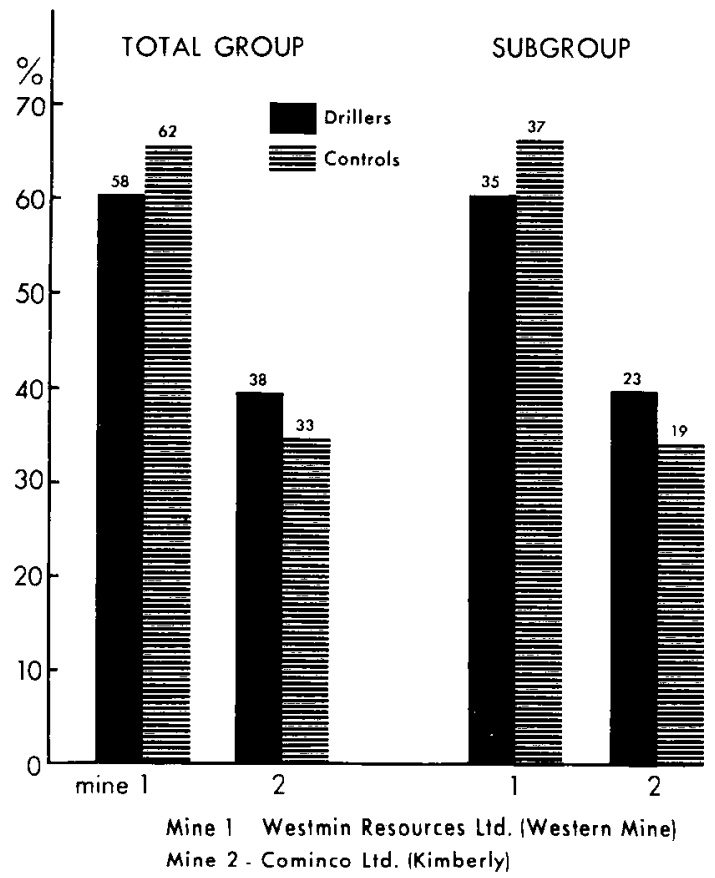

Figure 1. Percentage of the total group and of the subgroups of drillers and referents (controls) from each mine site. mean of 7.2 (SE 0.9) years and a median of 7.5 years. In general the operators had difficulty in recalling when symptoms initially developed. Among the drill operators blanching symptoms were the most common among the middle three digits on either hand; little involvement of the thumbs was noted.

The presence of vascular symptoms according to duration of vibration exposure is indicated for the driller subgroup in figure 3. Twenty-five percent indicated

Table 1. Exclusion criteria used in establishing the subgroups.

\begin{tabular}{lrrrrrr}
\hline \multirow{2}{*}{ Criterion } & \multicolumn{2}{c}{ Drillers } & & \multicolumn{2}{c}{ Referents } \\
\cline { 2 - 3 } \cline { 7 - 8 } & $\mathrm{N}$ & $\%$ & & $\mathrm{~N}$ & $\%$ \\
\hline Primary Raynaud's disease & - & 0 & & - & 0 \\
$\begin{array}{l}\text { History of intensive hand-arm } \\
\text { vibration exposure }\end{array}$ & 5 & 5.2 & & 11 & 11.6 \\
$\begin{array}{l}\text { Severe hand-arm trauma } \\
\text { History of possible secondary }\end{array}$ & 12 & 12.5 & & 10 & 10.5 \\
Raynaud's disease factor & & & & & & \\
More than one of above & 13 & 13.5 & & 8 & 8.4 \\
\hline Total & 8 & 8.3 & & 10 & 10.5 \\
\hline
\end{tabular}

a Excludes jack-leg or stopper exposure for driller group.

b Excludes vibration exposure or trauma. Includes physician diagnosed hypertension, diabetes, rheumatoid arthritis, polio, etc.

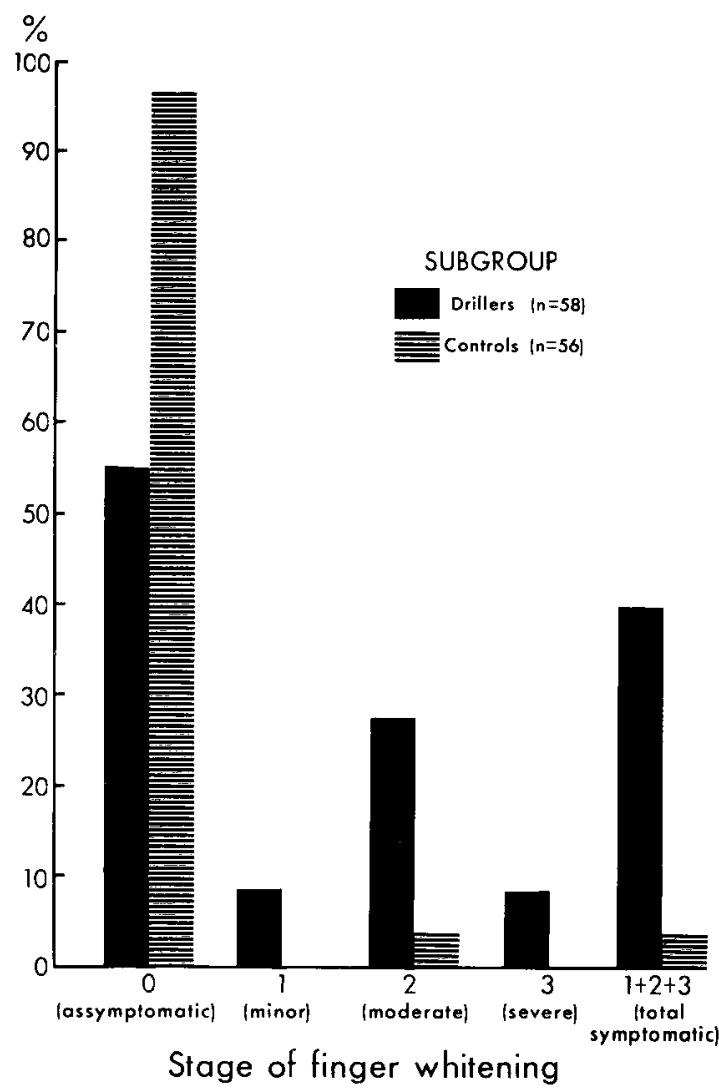

Figure 2. Percentage of the subgroups of drillers and referents (controls) with various stages of vibration-induced white finger, as classified according to the stages of Taylor \& Pelmear (2). 


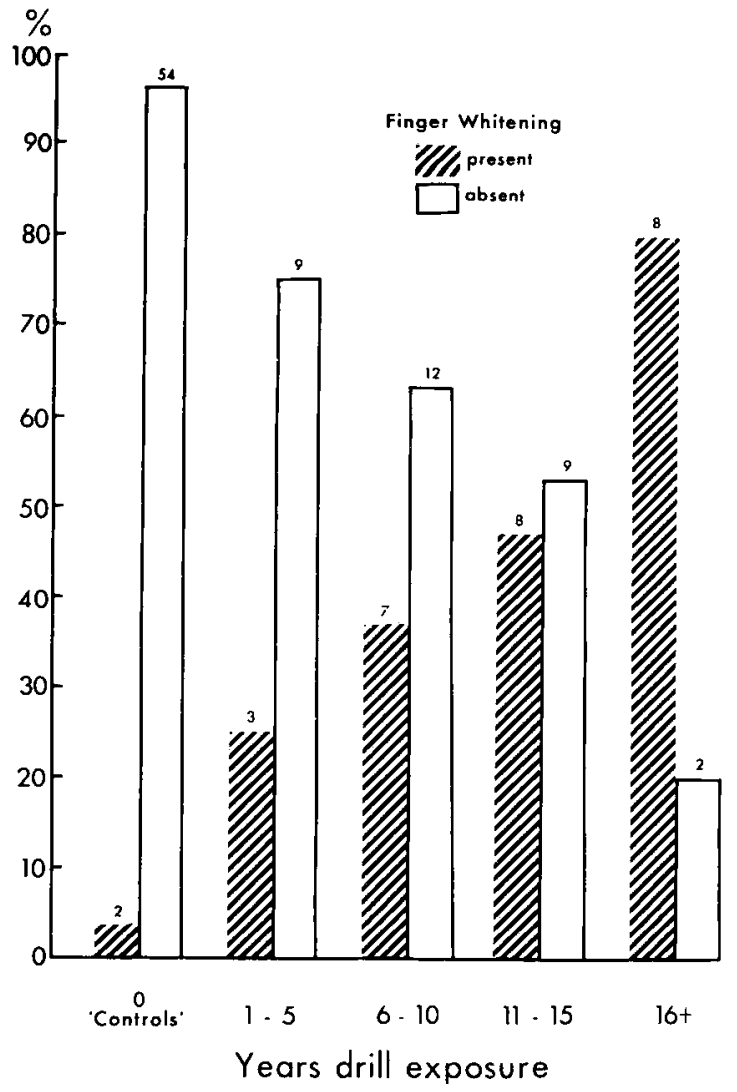

Figure 3. Raynaud's phenomenon in the subgroup of drillers according to the duration of drill exposure. The numerals at the top of the columns are the number of workers represented.

symptoms (stage 1, 2 or 3 ) with less than six years of exposure, while $80 \%$ of those drilling for 16 or more years were affected. A statistically significant positive association $(Z=2.56 ; p=0.005)$ was noted between years of exposure and presence of symptoms in the driller subgroup. A one-sided test was used in this analysis since there is general agreement among investigators that VWF is linearly rated to duration of exposure. Accordingly, the " $\mathrm{Z}$ " value was calculated from the square-root of the chi square.

Neurological digital symptoms such as tingling and/or numbing were noted for subjects without a current history of Raynaud's phenomenon (stage ${ }^{0} \mathrm{~T}, \mathrm{~N}$ ). Included in this category were $29 \%$ of the subgroup of drillers and $12 \%$ of the reference subgroup.

Tobacco use was examined in this study since cigarette smoking is strongly associated with certain circulatory disorders (14). Approximately $62 \%$ of the driller subgroup and $47 \%$ of the reference subgroup were current smokers. There was no statistical difference between these two groups ( $p=0.09$, twotailed test of proportions). In addition there was also no statistical difference in the proportion of excigarette smokers or those who had never smoked (analyzed separately) when the two subgroups were compared. Overall there was no significant difference in smoking

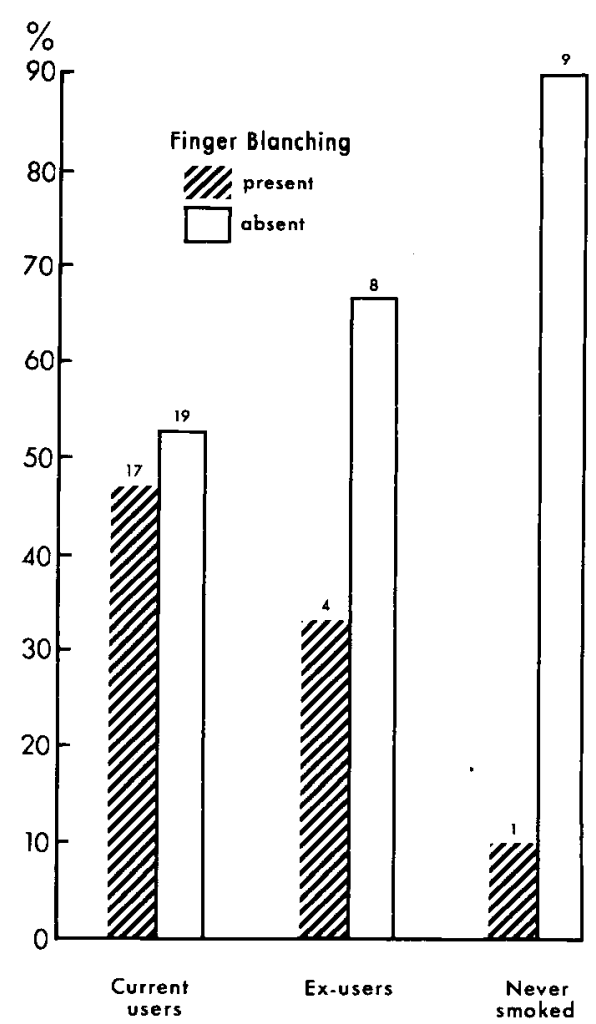

Figure 4. Smoking status (current users, ex-users, never smoked) and the percentage of the subgroup of drillers with vascular symptoms. The numerals at the top of the columns are the numbers of workers represented.

patterns among the two subgroups $\left(X^{2}=2.96\right.$; $\mathrm{p}=0.228$ ). Therefore smoking is unlikely to account for the differences in disease frequency that may have occurred between the two subgroups. In addition there was no significant difference in terms of years of vibration exposure $(0-5,6-10, \geq 11)$ and presence and absence of Raynaud's phenomenon among current smokers $\left(\mathrm{X}^{2}=1.74, \mathrm{p}=0.418\right)$, exusers $\left(\mathrm{X}^{2}=\right.$ $3.64, \mathrm{p}=0.162)$, and those who had never smoked $\left(\mathrm{X}^{2}=1.67, \mathrm{p}=0.435\right)$. Therefore years of vibration exposure cannot explain the possible difference among the various smoking categories. Cigarette smoking and the presence or absence of blanching symptoms in the driller subgroup is illustrated in figure 4 . There was an overall significant association in this group (Fisher's exact probability $=0.045$ ) in the comparison of smoking status and the presence or absence of Raynaud's phenomenon. In general there was a significant decline in symptoms in the driller subgroup when the current users were compared with the exusers and the exusers were compared with those who had never smoked (chi-square analysis for linear trend, $Z=2.14$, $p=0.016$ ). A one-tailed test was used for both of these statistical analyses since there was evidence from other studies of an association between VWF and cigarette smoking (17). 
Objective evidence of vascular abnormality is examined in table 2. On the basis of an earlier study (3) a positive test was defined as a failure of at least one finger to rewarm $0.2^{\circ} \mathrm{C}$ within $3 \mathrm{~min}$ after release from ischemia. On the whole there was reasonable agreement of the objective results with subjective symptoms on a group basis. Seventy-six percent of the driller subgroup reporting blanching episodes had a positive objective test, while $61 \%$ of symptom negative drillers had a negative test. Among the referents the objective evidence agreed with the subjective symptoms; however only two referents reported symptoms. Sixtyfive percent of the referents who were asymptomatic had a negative test.

The vibration levels of drills tested at the two sites are shown in table 3 . The mean levels recorded from 26 jack-leg drills from two different manufacturers (listed as A and B) and used at both mine sites were remarkably consistent and varied between 19-20 $\mathrm{m} / \mathrm{s}^{2}$. Similar mean values were recorded from three timber-supported stoper drills from manufacturer $\mathbf{A}$ at the Westmin site $\left(19 \mathrm{~m} / \mathrm{s}^{2}\right)$ and five timbersupported stoper drills from manufacturer $B$ at the Kimberly site $\left(20 \mathrm{~m} / \mathrm{s}^{2}\right)$. Two stoper drills from manufacturer $\mathbf{A}$, which were rock-supported, had higher levels of handle vibration for the equivalent timber-supported drill ( 32 versus $20 \mathrm{~m} / \mathrm{s}^{2}$ ). The mean vibration level from the stoper hose $\left(15 \mathrm{~m} / \mathrm{s}^{2}\right)$ did not differ significantly from that of the handle $\left(19 \mathrm{~m} / \mathrm{s}^{2}\right)$ of three tested drills.

Our study indicates that VWF is a common problem among rock drillers operating hand-held pneumatic drills at two large British Columbia mine sites. This conclusion is based on a prevalence of episodic blanching symptoms among $46 \%$ of the jack-leg and stoper operators whose symptoms could not be attributed to other possible confounding factors. The prevalence of VWF among an equivalent reference group unexposed to prolonged intense hand-arm vibration at the same sites was only $4 \%$. These data agree with those of other studies reporting a high prevalence of VWF (50-91 \%) among rock drillers in Japan (8, 11), Italy (5), Sweden (10), France (15), Bulgaria (12), and Great Britain $(4,16)$.

There was considerable variation in the reported latency times for the onset of blanching episodes, with a range of 1 to 14 years. Part of this variation may be due to individual differences in work practices affecting vibration exposure to the hands, for example, grip strength and average daily handle contact time. Inaccuracies in estimating the exact year of the onset of symptoms in a single terminal phalanx may also be another important factor. Some workers had poor memories, and others simply may not have recognized initial symptoms. Part of the difficulty in recalling early symptoms may be associated with the fact that only $35 \%$ of the drillers considered blanching episodes to be symptoms of a disease state; the remaining $65 \%$ considered white fingers to be a nuisance or part of the job.

Typical vibration levels recorded from the handles of the drills currently used by the operators in this study $\left(19-32 \mathrm{~m} / \mathrm{s}^{2}\right)$ were excessive if compared to current guidelines in ISO/DIS 5349.2 (7). This standard suggests that $50 \%$ of the workers exposed to vibration levels of 19 to $32 \mathrm{~m} / \mathrm{s}^{2}$ will develop initial blanching symptoms after an exposure time of three to five years.

Table 2. Comparison of objective test ${ }^{\mathrm{a}}$ with symptomatology among subgroups.

\begin{tabular}{|c|c|c|c|c|}
\hline \multirow{3}{*}{$\begin{array}{l}\text { Subjective } \\
\text { symptom } \\
\text { (digital } \\
\text { whitening) }\end{array}$} & \multicolumn{4}{|c|}{ Objective test ${ }^{a}$} \\
\hline & \multicolumn{2}{|c|}{$\begin{array}{l}\text { Drillers } \\
(\mathrm{N}=58)\end{array}$} & \multicolumn{2}{|c|}{$\begin{array}{l}\text { Referents } \\
(N=56)\end{array}$} \\
\hline & $\begin{array}{c}\text { Negative } \\
(\%)\end{array}$ & $\begin{array}{c}\text { Positive } \\
(\%)\end{array}$ & $\begin{array}{c}\text { Negative } \\
(\%)\end{array}$ & $\begin{array}{c}\text { Positive } \\
(\%)\end{array}$ \\
\hline $\begin{array}{l}\text { No } \\
\text { Yes }\end{array}$ & $\begin{array}{l}61 \\
24\end{array}$ & $\begin{array}{l}39 \\
76\end{array}$ & 65 & $\begin{array}{r}35 \\
100\end{array}$ \\
\hline
\end{tabular}

a Prolonged rewarming after cold provocation and ischemia.

Table 3. Weighted 4-h equivalent acceleration levels.

\begin{tabular}{|c|c|c|c|c|c|c|}
\hline \multirow[b]{3}{*}{ Drilla } & \multicolumn{6}{|c|}{ Mine } \\
\hline & \multicolumn{3}{|c|}{ Westmin Resources } & \multicolumn{3}{|c|}{ Cominco } \\
\hline & $\begin{array}{l}\text { Number of } \\
\text { borings }\end{array}$ & $\begin{array}{c}\text { Mean } \\
\text { acceleration } \\
\text { level } \\
\left(\mathrm{m} / \mathrm{s}^{2}\right)\end{array}$ & $\begin{array}{c}\text { Number of } \\
\text { drills } \\
\text { tested }\end{array}$ & $\begin{array}{l}\text { Number of } \\
\text { borings }\end{array}$ & $\begin{array}{c}\text { Mean } \\
\text { acceleration } \\
\text { level } \\
\left(\mathrm{m} / \mathrm{s}^{2}\right)\end{array}$ & $\begin{array}{c}\text { Number of } \\
\text { drills } \\
\text { tested }\end{array}$ \\
\hline Jack-leg (A) & 4 & 19 & 4 & 8 & 19 & 4 \\
\hline Jack-leg (B) & 40 & 20 & 14 & 9 & 20 & 4 \\
\hline $\begin{array}{l}\text { Stoper (A) } \\
\text { (timber supported) }\end{array}$ & $\cdots$ & $\cdots$ & $\cdots$ & 10 & 19 & 3 \\
\hline $\begin{array}{l}\text { Stoper }(A) \\
\text { (rock supported) }\end{array}$ & . & $\cdots$ & . & 5 & 32 & 2 \\
\hline $\begin{array}{l}\text { Stoper (B) } \\
\text { (timber supported) }\end{array}$ & 36 & 20 & 5 & . & $\cdots$ & . \\
\hline Stoper hose & . & 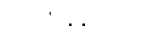 & - . & 6 & 15 & 3 \\
\hline
\end{tabular}

a Letters represent drills from different manufacturers. 
Data from this study indicate a median latency interval of 7.5 years. However, this value may be exaggerated since most drillers had difficulty in remembering accurately when a fingertip was first affected. In any case, the vibration levels of typical drills used in a production capacity at the study sites were well above the threshold levels of $2 \mathrm{~m} / \mathrm{s}^{2}$ or less that are recommended to prevent the onset of VWF in workers exposed to vibration throughout each workday of a working lifetime (2).

It should be noted that pneumatic drill design has remained largely unchanged since the 1950 s when the jack-leg drill was introduced (18). Evidence presented in this study suggests that jack-leg and stoper drills should be modified to reduce vibration levels substantially to meet current guidelines (7). Until this reduction is achieved more reliance should be placed on worker education, as outlined in ISO/DIS 5349.2 (7), and mechanized drilling using jumbo and diamond drills where the operator's hands are not exposed to excessive vibration.

\section{Acknowledgments}

This study was funded by grants from the BC Health Care Research Foundation, the BC Ministry of Energy, Mines and Petroleum Resources, the BC Mining Association, the Canadian Association of Industrial, Mechanical and Allied Workers, the International Union of Operating Engineers, and the United Steelworkers of America.

\section{References}

1. Ashe WF, Williams N. Occupational Raynaud's II, further studies of this disorder in uranium mine workers. Arch Environ Health 9 (1964) 425-433.

2. Brammer AJ. Threshold limit for hand-arm vibration exposure throughout the workday. In: Brammer AJ, Taylor W, ed. Vibration eifects on the hand and arm in industry. John Wiley \& Sons, New York, NY 1982, pp 291-301.

3. Brubaker RL, Mackenzie CJG, Eng PR, Bates DV. Vibration white finger disease among tree fellers in British Columbia. J Occup Med 25 (1983): 5, 403--408.

4. Chatterjee DS, Petrie A, Taylor W. Prevalence of vibration-induced white finger in fluorospar mines in Weardale. Br J Ind Med 35 (1978) 208-218.
5. Guiliano G, Cavina C, Bartoli V, Dorigo B, Focarde L. Aerteriography findings in vibration and vascular disease of upper limbs (vibration angiography) [in Italian]. Lav Um 26 (1974): 6, 161-197.

6. Hutton SG, Brubaker RL. Vibration effects on mine workers. CIM Bull 75 (1982): 838, 85-93.

7. International Organization for Standardization. Guidelines for the measurement and the assessment of human exposure to hand-transmitted vibration. Geneva 1984. (ISO/DIS 5349.2-1984).

8. Iwata $H$. Effects of rock drills on operators: Part 2. Survey and examination on Raynaud's phenomenon. Ind Health 6 (1968) 37-47.

9. Krahenbuhl B. Une methode utile pour le diagnostic du phenomene de Raynaud: La suppression par le froid de l'hyperemie reactionnelle postischimneque digitale. Schweiz med Wochenschr 107 (1977) 1831-1833.

10. Lidström IM. Vibration injury in rock drillers, chisellers and grinders. In: Wasserman DE, Taylor W, Curry MG, ed. Proceedings of the international occupational hand-arm vibration conference. National Institute for Occupational Safety and Health, Cincinnati, $\mathrm{OH} 1977$, pp 77-84. (DHEW publication no 77-170).

11. Matsumoto T, Yamada S, Hisanaga N, Harada N, Kaneda $K$. On vibration hazards in rock-drill operators of a metal mine. Jpn J Ind Health 19 (1977) 256-265.

12. Mitrev $\mathrm{N}$. On the evolution of the vibration disease among the miners from an ore-mining establishment. Fol Med 19 (1977) 11-15.

13. Miwa T. Vibration-isolation systems for hand-held vibrating tools. In: Brammer AJ, Taylor W, ed. Vibration effects on the hand and arm in industry. John Wiley \& Sons, New York, NY 1982, pp 302-310.

14. Mustard JF. Cigarette smoking, atherosclerosis and its clinical complications. Can Public Health J 72 (1981): 6, 385-388.

15. Robert J, Moreau P, Cavelier C, Chameaud J. Troubles angio-neurotiques professionals provoques par les vibrations d'outils manuels: Enquete chez 100 mineurs utilisant des marteaux perforateurs pneumatiques. Arch Mal Prof Med Trav Secur Soc 38 (1977): 4-5, 437-455.

16. Rodgers LA, Eglin D, Hart WFD. Rock-drill vibration and white fingers in miners. In: Brammer AJ, Taylor $W$, ed. Vibration effects on the hand and arm in industry. John Wiley \& Sons, New York, NY 1982, pp $317-323$.

17. Theriault G, De Guire L, Gingras S, Laroche G. Raynaud's phenomenon in forestry workers in Quebec. Can Med Assoc J 126 (1982) 1404-1408.

18. Williams $N$. Hazards of mining uranium and some rarer ores and the use of vibrating tools. In: Rogan JM, ed. Medicine in the mining industry. W Heinemann Medical Books, London 1972, pp 99-127.

19. Williams N, Riegert AL. Raynaud's phenomenon of occupational origin in uranium miners. In: Proceedings of the 13th international congress on occupational health. New York, NY 1961, pp 819-825. 